\title{
Article \\ Be Careful, Ye Catholic: The Entanglement of Mormonism and Money in Peru
}

\author{
Jason Palmer
}

check for

updates

Citation: Palmer, Jason. 2021.

Be Careful, Ye Catholic:

The Entanglement of Mormonism

and Money in Peru. Religions 12: 246

https://doi.org/10.3390/rel12040246

Academic Editors: Matthew Bowman, Caroline Kline and Amy Hoyt

Received: 13 February 2021

Accepted: 29 March 2021

Published: 31 March 2021

Publisher's Note: MDPI stays neutral with regard to jurisdictional claims in published maps and institutional affiliations.

Copyright: (C) 2021 by the author. Licensee MDPI, Basel, Switzerland. This article is an open access article distributed under the terms and conditions of the Creative Commons Attribution (CC BY) license (https:/ / creativecommons.org/licenses/by/ $4.0 /)$.
Department of Anthropology, School of Social Sciences, University of California, Irvine, CA 92697, USA; jasoncharlespalmer@hotmail.com

\begin{abstract}
Globalization is not only the feverish insistence that land's superfluity is increasing exponentially, but it is also the willful ignorance of the reality underlying that illusion: Distance has not been annihilated. Distance, and the land it spans, is more important than ever. Globalization imagines away the land's importance because of whom it imagines to be "of the land". This entity, indigeneity, threatens to expose the lie upon which globalization is founded. According to many people of the land surrounding the mid-Andean city of Arequipa, Peru, globalization's promise of unidirectional wealth accumulation severs their connection to sustainable, terrestrial cyclicity. For some of these arequipeños, few institutions embody this existential disruption more menacingly than The Church of Jesus Christ of Latter-Day Saints. Mormonism, therefore, becomes a material and mythological threat to the lifeways of their land. This article grounds the fraught, mimetic relationship between globalization and land in Peru through the lens of anti-Mormonism.
\end{abstract}

Keywords: globalization; indigeneity; money; Mormonism; Peru; sacred place

Attention, Catholics, Attention. The insidious and anti-gospel propaganda of the Mormons, backed by an impressive and variegated literature, has found its way to our peaceful plot of arequipeño earth, a place that has always been so distinguished for its most untarnished Catholicism that it is possible for us to affirm that if one is not católico, one is not arequipeño.

Be careful, ye Catholic. Do not let yourself be swindled by these Mormon Yankees who speculate upon your naivete, earning abundant dollars for every Catholic that they can trap in their nets. The gifts that they bestow upon you may seem to you fruitful in their economic aspect, but it would be an unmentionable shame if, for a few insignificant material advantages, you renounced that one thing which is more valuable than all others in Life: your faith. (Escuela Tipográfica Salesiana 1964 , para. $1,3^{1}$ )

\section{Deep Money}

As this epigraph demonstrates in its language of earth and dollars, the anti-Mormon propaganda spread throughout Arequipa, Peru, in the early 1960s was deliberate in its focus on international speculation and financial materiality. For the arequipeño archbishop who magnified this focus and for the Catholic community that mythologized it, The Church of Jesus Christ of Latter-Day Saints was dangerous, not because of its polygamy, but because of its material money and that money's inappropriate intertwinement with soul. In this article, I begin to unpack the complexity of this intertwinement and the relationship that it has to both globalization and to the ubiquity of the Mormon-is-money stereotype in Peru.

I must first emphasize the provisionality of this article and the narrowness of its argument. This article is not a report on culminated ethnographic research combined with

\footnotetext{
1 This and all other Spanish-original excerpts of speech and text were translated by the author.
} 
an extensive literature review on official Catholicism in Arequipa-the Rome of Peru-and its own complex interactions with both a rich array of multitemporal Andean spiritualities (Nash 1993) and conflicting spectrum of ontologies regarding land and material resources (Harrison 2015). Instead, this article is a glimpse into why such a report would be important. Rather than building up to a solid theoretical conclusion, this article is merely designed to establish a preliminary realm of inquiry surrounding Mormon materiality in Arequipa, Peru. Furthermore, this article is not even located in the center of that realm.

This article, like arequipeño Mormonism itself, is located "off to the side" (Palmer and Knowlton 2020, p. 401). It rests inside one of the many gaps within "Andean Mormonism's" sacred margins. Within other gaps lay precursors to the "Andean" half of that oxymoronic and problematic label, which include a palimpsestic overlay of colonizations atop overlapping hierarchies of difference based on the altitude of one's hometown, the hue of one's skin, the religion in one's "blood" (Martínez 2011), the caste of one's ancestral mix, and the years of one's formal education (De La Cadena 2000), to name but a few. Within still other gaps lay precursors to the "Mormon" half of "Andean Mormonism", which include the rise of Western modernity, the conflicted separation of economics from religion and religion from kinship (Franklin 2002), and the neoliberal modularity and extractivism of The Church of Jesus Christ of Latter-Day Saints' correlated globalization (Brooks 2018). This article fills neither of these gaps. In other words, this article is neither about Andeanism nor Mormonism, much less Andean Mormonism. It is simply about arequipeño — specifically carmenalteño —anti-Mormonism.

As an anthropologist of Mormonism in Peru since 2014, I have talked to hundreds of individuals from diverse socioeconomic, national, and religious backgrounds-from the Salt Lake City-based architect of the newly dedicated Mormon temple in Arequipa's one hundred percent Catholic neighborhood of Carmen Alto to that temple's Catholic neighbor now forced to harvest her spinach in the shadow of its golden statue of the ancient American Christian prophet, Moroni (Figure 1). Though my research question has never been, "Why do Peruvian Catholics become Peruvian Mormons?" everyone feels that they must tell me the answer anyway: money. Mormonism's real and mythological association with money and with globalized consumerism may be why the archbishop of Arequipa went from threatening to burn Books of Mormon in 1962 to attending - as a VIP — the Arequipa temple groundbreaking in Carmen Alto in 2017. Perhaps the deep and anti-seismic foundation of that temple guards the entrance to a subterranean motherlode, common to Andean lore, infused with an elemental energy capable of seducing even the archbishop.

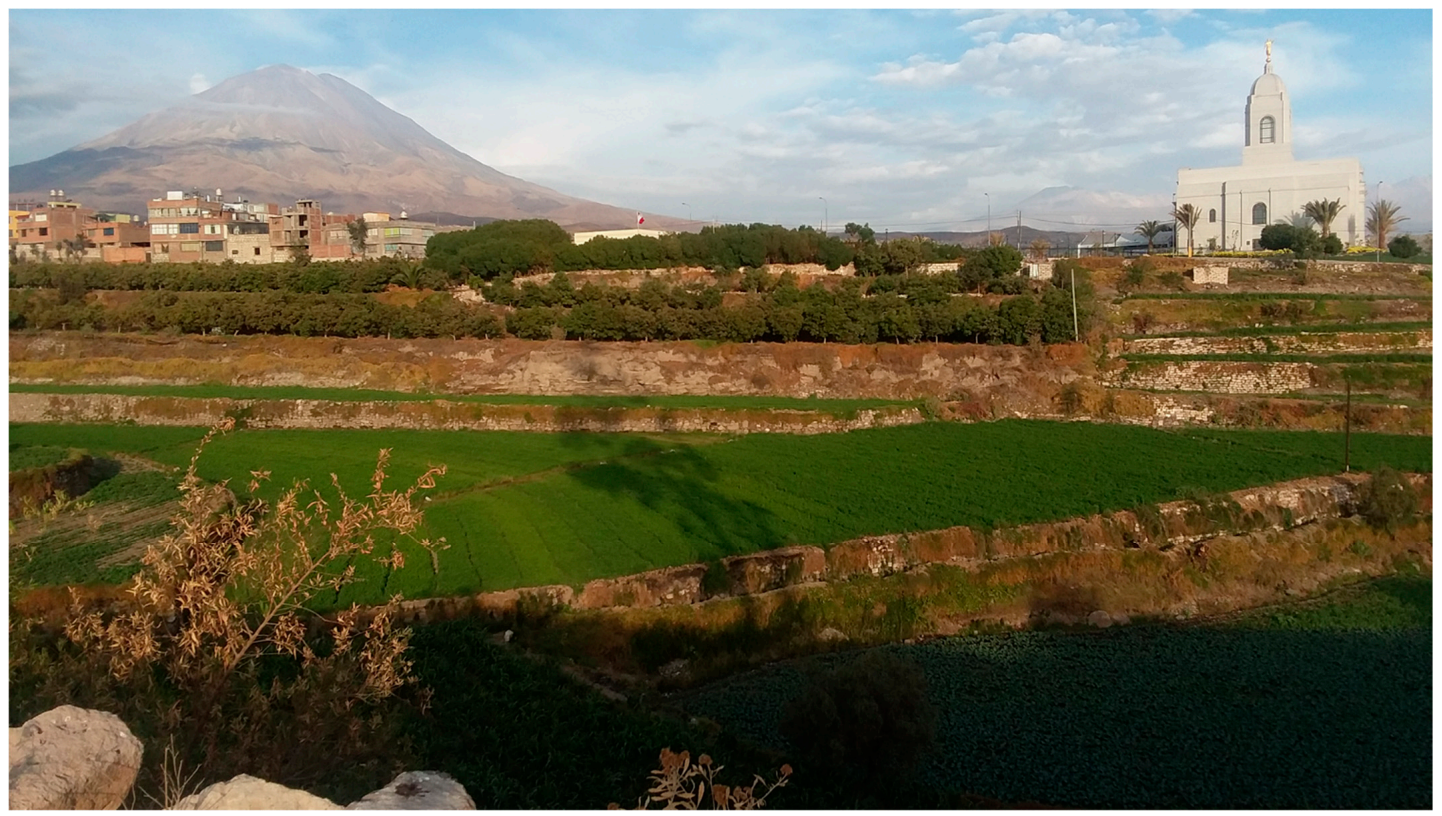

Figure 1. The Arequipa, Peru temple (right) is the house of the Lord for Mormons. It sits on the skirts of the volcano, Misti (left), a deity for many arequipeños. December 2019. ${ }^{2}$ 
The mythic proportions such imaginings acquire point to even more contradictory entanglements of international wealth and transnational religion as I probe deeper into my conversations with non-Mormon Peruvians and with the anti-Mormon archive. These depths tunnel through dialectics of matter vs. spirit and cyclicity vs. directionality in Peru, demonstrating that money's entanglement with Mormonism's globalization in the minds of Carmen Alto's residents (carmenalteños) is more profound than a simple, implicit association. I make no claims as to the precise depth of this profundity. All I am arguing is that some non-Mormons in Arequipa have created a mythology around Mormons and money and that this mythology might reveal something about the mythmakers, the mythologized, and globalization itself.

\section{Globalization vs. Indigeneity}

I also make no argument as to the cause of this profundity, but I think it might have something to do with carmenalteños' claims to a complex assemblage that I am choosing to call "indigeneity" and the general opinion in Carmen Alto that globalization is in tension with this assemblage. Indigeneity exists entirely on its own terms and certainly does not need academics to constantly place it in tension with other terms deemed its opposite. However, since carmenalteños themselves often make a dichotomous connection between their landed lifeways and globalization, and since hegemonic, US schemes of globalization imagine Peru to be an indigenous nation, I will proceed to imagine what globalization might look like if indigeneity were its opposite. Would globalization and indigeneity become a primordial dyad with a shared genesis? Like Cain and Abel, would the one exist only at the expense of the other? If so, this subtractive polarization is reflected in the idea that indigeneity implies a people tied to a land that, in Western economic models of globalization, is one of the four factors of production. These factors include land, labor, capital, and the drive to convert the previous three factors, imagined as scarce, into consumable goods imagined as even scarcer. This feat of collective imagination becomes increasingly esoteric given that money, a mere idea with no backing other than a shared belief, is the unit of measure for all economic interactions. Understanding the mystical levels of imagination required for Western economic theory to work, a definition for the Western cultural concept known as "globalization" begins to take shape. Globalization is that force which is able to increasingly exploit land, and the people of the land, by shrouding that exploitation in the mythology that information and transportation technologies make land increasingly superfluous. Indigenous people lose their land to colonization, but globalization assuages the colonial conscience through its fanciful dogma that landincluding the distance that spans it and the humans who care for it-somehow matters less than it used to.

Indigeneity, as it appears here in my dichotomous revery but not as it appears in the reality of actual Indigenous people, did not exist before its antithesis, globalization. In fact, under this experimental revery, there are people on the planet for whom indigeneity may still not exist. Ironically, indigeneity might not exist for the very people whom the wealthiest beneficiaries of globalization would consider the most indigenous. The British anthropologist, Andrew Canessa (2012) studied among such people in the highlands of the Bolivian Andes. His study participants cultivated the same land that their pre-Inca ancestors cultivated, yet they did not consider themselves Indigenous, at least not in the 1990s when Canessa conducted his study among them, which, admittedly, was before Bolivian president Evo Morales brought indigeneity into national prominence. In the 1990s, they considered themselves "people", which in Aymara is jaqi. Non-Aymara speakers tend to use the word "jaqi" synonymously with "Indigenous", which for the US Bureau of Indian Affairs, is a term tied to blood quantum. However, for Canessa's specific group of jaqi, being jaqi had absolutely nothing to do with blood and everything to do with a lifestyle of cyclical, mutual indebtedness to human and nonhuman others in a tight, known (not

2 All photographs are credited to the author unless otherwise noted. 
imagined), coresident community. This definition allowed Canessa himself to become jaqi. If "Indigenous" meant little to people relatively unaffected by globalization whom settler scholars like myself would consider the most "authentically" indigenous, what might indigeneity mean to my study participants in Peru's second most globalized, neoliberal, and populous city, Arequipa?

According to the captions on the maps in Arequipa's municipal museum designed by the city's elite, ever since the mines of Potosi began to falter in the 1600s, Arequipa has "suffered" "invasions" of "immigrants" from higher up in the mountains. Today, an extremely large minority in Arequipa was born near the altiplano city of Puno. This means that puneños occupy Arequipa's lowest social category, that of recién bajados (recently come down from the mountains), and that they will require the most "de-Indianization" (De La Cadena 2000, p. 6) in order to adopt the more socially acceptable form of indigeneity captured in the identity category "arequipeño neto". Those who already consider themselves arequipeños netos welcome neither puneños nor their squatter communities on the outskirts of the city, communities that arequipeños, like their limeño counterparts (Gandolfo 2009), call "invasiones". Though I personally fail to see the difference (my rods and cones will likely never become acculturated to the nuances of Peruvian colorism) puneños are said to have a darker skin tone than arequipeños netos, who admit that their city is called La Ciudad Blanca (the white city) for reasons more racially complex than the white volcanic stone out of which it was constructed.

Arequipa's position halfway between the coast (racialized as wealthy and white) and the mountains (racialized as poor and brown) causes it to periodically upend all of the aforementioned hierarchies of difference that are comparatively stable in much of Peru. Arequipa's geographic positionality alone, not to mention its structural, cultural, migratory, and religious history, breaks dichotomies that divide the world comfortably into indigeneity vs. globalization, science vs. religion, Andeanism vs. Catholicism, and spirit vs. matter. To make any sort of generalizable argument regarding Arequipa, however narrow, is to risk essentializing any one of its many plurinational realities. Arequipa is not at all representative of "the Andes" (nothing is), and yet, throughout this article, I tend to blur jaqi, Andeans, Peruvians, and arequipeños as if they were interchangeable or as if arequipeños were the alchemical result of adding unchangeable jaqi traits from an Andean primordium to damnable Spanish traits from modernity. As a settler scholar writing from the unceded territory of the Tongva and Acjachemen, my ethnography is particularly unethical, and I offer no excuse for it. By way of explanation, however, I do not mean with these slippages to essentialize "Andeanness". Rather, I mean to create a multiplicity of imaginaries similar to composite, fictional characters. The images of indigeneity that I paint in these pages do not exist in any one person's reality, and they probably reflect my own "settler adoption fantasy" (Tuck and Yang 2012, p. 14) more than anything else, but perhaps their amalgamation can be used to arrive at a truth about Mormon money mythologies in Arequipa that any one person's reality would miss.

Every person in Arequipa has their own complex identification with and feelings about what I term "indigeneity", but what they term "lo originario" when speaking with more propriety, or "lo indio" when speaking with less. Most arequipeño identities involve some tie to the lands and peoples of pre-Hispanic Peru. Most residents of Carmen Alto, a small agrarian town within the greater region of Arequipa, consider themselves to be descendants of lonccos. Loncco identity is a facet of greater arequipeño neto identity. Lonccos, also known as characatos, descend from Spanish colonists in the 1600s who began to occupy a decreasing level of status in greater Peruvian society as they moved to higher elevations away from coastal cities, had offspring with indios (Peruvians from thousands of linguistically distinct cultural groups all lumped into one misnamed mass near the bottom of a particular Spanish viceroy's invented system of racial caste), founded ranching towns, and inhabited a more lawless culture than that which dominated aristocratic Lima. Despising the pompousness of Lima, this equine people, similar to the vaqueros of Alta California, the llaneros of Venezuela, and the gauchos of Argentina, formulated a distinct 
identity that, today, takes pride in certain aspects of what might be termed indigeneity. These aspects include the infusion of Quechua loan words into its Spanish dialect and its status as being of the land of Arequipa for over 400 years. In my experience, the descendants of lonccos tend to have more pride in their Spanish ancestry than in their indio ancestry, mostly because colorism's predilection for light skin is a powerful force in a Peruvian national culture complexly interwoven with antiblackness and anti-indigeneity. Young descendants of lonccos do not usually claim to be lonccos themselves, even though they wish they could. Loncco, like jaqi, is an identity that has more to do with lifestyle than heredity. Arequipeños netos often tell me that their own mother was a loncca, but that they, alas, have forgotten the poetry, music, and culinary skills that give that identity legitimacy. Elderly carmenalteños, on the other hand, often readily claim loncco identity.

Though few people in Arequipa, including migrants from nearby Quechua-speaking autochthonous villages, "identify as" Indigenous in the same way that a Cherokee Nation tribal citizen in the US might, everyone in Arequipa, even very light skinned people, whom I ask about the Spanish conquest of the Incas, grammatically identify with the conquered, not with the conquerors. Whether they think of the conquest as a good thing or as a bad thing-and The Book of Mormon leads most arequipeño Mormons to think of it as a good thing - their responses invariably include, "those Spaniards conquered us", never "we Spaniards conquered them". Though this hardly counts as identifying with indigeneity, it may point to a multivalent form of arequipeño identity that approximates indigeneity. Regarding my dichotomous imaginary of globalization, however, most people living in Arequipa today-be they puneños, carmenalteños, lonccos, arequipeños netos, none of the above, or a mix of any-reflect indigeneity in a more pressing sense: They are by and large the victims of globalization, not the beneficiaries. Furthermore, accumulated wealth is the symbol of their victimization, and few institutions display that symbol with more zeal than Mormonism.

\section{Suck and Syphon}

Before I get into the anti-Mormon understandings about globalization and gold in Arequipa, I will provide a bit of ethnographic evidence establishing that there is indeed a strong implicit association of Mormons with money in the mid-Andean region of Southern Peru. My confidence in the ubiquity of this association stems from dozens of discussions with taxi drivers all over Arequipa who transport me from one Mormon edifice to another whenever I am in their proud city. Most taxi drivers in Arequipa, many of whom are puneños, know the locations of its 25 Mormon chapels (meeting houses) as these are extremely distinctive in their un-arequipeño style, high cost, and high speed of construction. Rather than asking me what I know about Mormonism as they pick me up from these expensive-looking foreign buildings, taxi drivers usually alert me to disturbing tidbits of Mormon mystery involving money.

There was one building, however, that most taxi drivers in 2018 and 2019 did not yet recognize as Mormon. It appeared to arise overnight. Suddenly, one spring day in 2018, its unfinished steel armature dominated the skyline high on the hills above Arequipa's most traditionally arequipeño colonial neighborhoods. Because it was vastly larger and more ostentatious than any Mormon chapel they had ever seen, taxi drivers had no way of knowing that this new structure- the holy Arequipa temple-was Mormon. Of course, when I told them it was Mormon, it made perfect sense to them that Mormons would have something so luxurious at the ready in their secret architectural arsenal.

Though I missed the media event wherein the temple spire was crowned with a larger-than-life golden trumpeter-Moroni-a symbol of Mormonism's globe-spanning gospel sound, I did attend the dedication ritual of the Arequipa temple on 15 December 2019. The following field note that I wrote afterwards exemplifies the way boundaries blur among myth, rumor, and reality in the creation of the Mormon-is-money stereotype.

I left the temple gardens and started to walk down the steep hill to Avenida Ejército, but that was going to take forever, so I hailed a taxi. 
I pretended I wasn't Mormon and asked the driver, "what in the world was that huge, bright building where you picked me up?"

"What, aren't you a member of it?" he retorted incredulously.

"No," I lied.

"Well, it's an evangelical church. It's a strange church because you can't go in. You have to have a special invitation. It just popped up like two months ago, built very quickly."

I pretended like that information sparked some memory, and I said, "Oh, it must be a Mormon temple."

"Yes, that's it. Mormon, not evangelical. It is Mormon, and those Mormons are la muerte ${ }^{3}$."

I revealed that I knew about the Mormons because "they come from the US just like me," and he asked me yet again, "are you positive you're not a Mormon? You sure look like one. Anyway, if you are a Mormon you have to pay Mormon headquarters a full 10 percent of your income. So, if you make 5000 soles, you have to pay 500. And they have a professional department that goes and investigates your workplace and verifies how much you make and records whether or not you are really paying 10 percent. They have another department, like our Defensoría del Niño y del Adolescente del Perú (DNA) [the Peruvian equivalent of Child and Family Services, CFS], that goes into your home and sees how many kids you have and makes sure that you have them enrolled in Mormon schools."

I asked, "so there are Mormon schools in Arequipa?" even though I knew there weren't any.

He said, "there must be Mormon schools here if there are so many Mormons here. In fact, that is what the temple is, a Mormon school. They are even opening up a nursery school behind it."

Later, I saw what he was talking about. There is a huge grass area behind the temple's distribution center [a store where Mormons buy their sacred undergarments, church memorabilia, and books, all of which are imported from Salt Lake City] where temple volunteers had set up a small playground to entertain children who waited for their parents to finish the adult-only temple rituals. The taxi driver must have thought it was a kindergarten.

This taxi driver had heard financial rumors and had seen lavish buildings. He mixed these cues with his own globalization logics to fabricate, before my very eyes, a coherent Mormon narrative. In his mindset, common in Peru, there is little difference between the religious education that prepares children to be moral, Catholic citizens and the secular Peruvian education that prepares them to become professionals, creating homegrown wealth that will someday enrich the nation instead of enriching, as it does currently, the US, the UK, and Chile. Because globalization has inserted a new religion into PeruMormonism - he assumes this religion must be at odds with the local nation-building goals of Peruvian public schools. Following this logic, it seems natural that Mormonism would require its own school system. For one thing, how else would Mormons train future employees to staff their ecclesiastical IRS- and CFS-like spy agencies? However, the main reason many arequipeños erroneously believe that Mormons have their own schools in Arequipa is that the Mormon religion is seen as incompatible with locality. Mormons, according to this thought process, surely must have a secular education system that matches their religion in much the same way that Peruvian public schools are thought to match Catholicism. From what some arequipeños observe, a school system appropriate to Mormonism would be one designed to disrupt the flow of Peru's local wealth, syphon off ten percent of it, and pool that percentage at a headquarters on the other side of the globe. In other words, in the world view of this taxi driver and of many arequipeños like

3 La muerte is a Peruvian expression that means "they will be the death of us"; it usually implies laughing to death. 
him, globalization, and its embodiment in Mormonism, is a disjointing, disunifying power that endorses pillage and hoarding rather than locality and sharing.

For many academics in both the US and Arequipa, however, globalization implies that the ever-present evolution of our planet has somehow become increasingly shared. Scientific moves to call the current geologic epoch, "the Anthropocene", attempt to solidify our age as one of unprecedented global interconnectedness. According to proponents of the term Anthropocene, we humans are such a coherent force, rather than many separate communities, that an entire geologic ecology should be defined by our collective actions. Ironically, the collective actions that justify calling our time the Anthropocene are actions antithetical to the Earth's most collectivist societies. These actions include short circuiting, syphoning, and accumulating.

Geologists have justified the boundaries of other geologic epochs through the distinct layers that certain nonhumans (i.e., ferns and volcanoes) left encased in stone and ice. They justify the Anthropocene's border by pointing to the way humans leave behind layers of stratigraphic change in the form of a nonhuman substance from a past epoch that some humans burn-fossil fuels. In the Anthropocene, sucking that substance from certain lands and channeling it to fuel others drives the global economy. According to world systems theory, places that happened to have mastered a naval force early on in the petroleum trade have made sure that its extraction perpetually enriches their lands by perpetually impoverishing others (Wallerstein 2004).

Naval force, however, has never worked alone in this globalized, unidirectional syphoning of wealth. It has always worked with religion. In fact, the man who wrote the globally bestselling 1890 book that kicked off the modern navy-building race among aspiring empires was a US officer who "held that the United States had an obligation to expand so that its civilization, culture, and religion could be spread abroad for the benefit of the more backward nations" (Zimmermann 1998, p. 5). In the Anthropocene, Protestant imperialism and economic imperialism are so intertwined that it is impossible to identify which one digs channels to tap the "backward nations" and which one syphons these nations' wealth through those channels. Per 1860s clergyman, Frederick Gates,

Missionaries ... are introducing ... modern science, steam ... electric power $\ldots$ and modern manufacture into foreign lands. The result will be eventually to multiply the productive power of foreign countries many times. This will enrich them as buyers of American products and enrich us as importers of their products. We are only in the very dawn of commerce, and we owe that dawn, with all its promise to the channels opened by Christian missionaries. $\left(\mathrm{O}^{\prime} \mathrm{Brien}\right.$ 1999, p. 53)

Sucking substances away from the places that produced them and using them instead to feed unsustainable forms of wealth accumulation is what connects globalization to anti-Mormon mythologies in Arequipa. Though there is a chasm between the ideal and the practice, maintaining a well-oiled, self-sustaining, closed cycle of reciprocity free of coagulated wealth remains part of the imaginary of an ideal lifestyle even in urban, capitalistic Arequipa today. People who hold to vestiges of this imaginary in the arequipeño neighborhood of Carmen Alto fear that globalization's ideal is to disrupt such cycles, syphon off their wealth, and crystalize it in powerful faraway lands. According to many carmenalteños, their ideal of cyclicity is at odds with globalization's ideal of directionality. These carmenalteños see Mormonism - with its opulent, multimillion-dollar constructions and other blatant displays of accumulated wealth - as siding with globalization in a concerted war against loncco lifeways. When carmenalteños see Mormon missionaries from powerful faraway lands and Mormon temples made from materials, ideologies, and labor from these same lands, they see wealth accumulated. And when they see wealth accumulated, they see wealth syphoned-wealth sucked, vampire-like, from some other unsuspecting community's cycle of reciprocity. They fear becoming that vampire's next victim, and those who designed the anti-Mormon literature in Arequipa in the 1960s capitalized on that fear. 
The first Mormon mission to officially include Peru was headquartered in Peru's largest city-Lima-in 1959. In 1964, the epigraphic pamphlet, inspired by one published in English in 1959 by Dr. L. Rumble (1974) of the London Catholic Truth Society, was distributed throughout Peru's second largest city-Arequipa-where Mormonism had already achieved a foothold even before the official Lima mission because of ties that connect deeply, terrestrially, and unsettlingly metallurgically to my argument in this article, which is this: Mormonism's stereotypic connection to money and globalization in the imaginations of the arequipeños to whom I spoke radiates deeply set fears and dangerous desires that cut to the very bedrock of their personhood.

\section{Reciprocal Personhood}

Inasmuch as the fading loncco identity of Carmen Alto contains, as carmenalteños themselves claim, cultural influences from ancestral Andean communities, the greater Andean ontology that non-Andean anthropologists call "substantialism" might elucidate some small facet of carmenalteño personhoods. The anthropologist Cecilia Busby (2006) defined substantialism as "the tendency to imbue qualities that Western ethnoscience would consider abstract or nonmaterial with certain material essence and a concern with the effects of flow or exchange of such qualities between people and things" (p. 85). In this ontology, the Andean person "is substantially connected to others and is not therefore a stable, bounded individual but rather a 'dividual,' constantly giving out and receiving parts of the self from others" (p. 86). Among some communities in Arequipa, particularly migrant communities from smaller Andean hamlets, one of these dividual parts is a soul thread that interlaces with others to form the weave that is the allyu, the community. The gaze, rather than the sincerity of words, becomes vital to discerning who is capable of ayni (reciprocity) in any given encounter and therefore part of one's allyu. Gaze looks at your ajayu (another part of your soul) as if ajayu were an object, but ayni changes your ajayu into a subject (Vega 2008). If you look at my ajayu first and it cannot look back, it might get stuck as being an object in that situation (Viveiros De Castro 1998). If you are a nonhuman person, like a stone, my ajayu could get stuck forever, layered into your stratigraphy. In generic Christian metaphysics, God is the ultimate gaze. Among communities where substantialism is a reality, however, I only exist in you and you only in me. My relatedness to you is what makes my personhood emerge. This is why Andean substantialists-who are also often "constructivists" as I describe below-dance together, eat together, and live together. This is the collective becoming of ayllu through ayni.

While I do not think that substantialism is an integral part of non-Mormon carmenalteño personhoods, I do think that it exerts a greater influence on them than it does on, say, Anglo Mormon personhoods in Utah. Because Anglo Mormons from Utah recently built a temple in Carmen Alto that became a public touchstone of seemingly incommensurable difference between carmenalteño and Mormon personhoods, I want to take a moment to magnify a related difference. This difference lies between two poles that I am just now writing into existence-the carmenalteño constructivist vs. the Mormon essentialist. A community is constructivist to the extent that it considers aspects of personhood, including gender, ancestry, and tellurian relatedness, to be molded through community influence. A community is essentialist to the extent that it considers these and other aspects to be innate, self-evident, or God given. I create these poles to briefly examine the space between them, not to solidify that space into a permanent crystal of cultural alterity. To create the polarization, I will be deliberately wielding jaqi constructivism, as described by Canessa (2012). I chose the jaqi because, from what I read in Canessa's ethnography, they appear at the extreme constructivist pole. This helps lengthen the continuum between constructivism and essentialism in my mind and makes it easier to place carmenalteños as decidedly more constructivist than Mormons. It must be noted, however, that there is absolutely no reason to think that, in ways other than constructivism, the jaqi are more culturally similar to carmenalteños than they are to Anglo Mormons simply because both jaqi and carmenalteños live in the Andes. There is no magical "Andeanness" floating in the ether of "the Andean 
world". Furthermore, simply because the jaqi live in relative rurality, there is no reason to think that contemporary jaqi belief systems resemble 1990s jaqi belief systems any more than contemporary Anglo Mormon belief systems resemble 1990s Anglo Mormon belief systems. Urban communities are not more prone to cultural change than rural ones. In other words, there are no humans on Earth today that at all resemble the jaqi that I am about to describe. If there ever were any, they, like all humans, have changed.

According to my reading of the way Canessa (2012) depicted his study participants in Bolivia, their jaqi (human) identity depended on a cycle of reciprocity with the human and the once human, on a vigilant ambivalence toward the nonhuman, and on a careful avoidance of the antihuman. The raw materials for the creation of a human would appear in the form of what essentialist Mormons might call a fully formed two-week-old infant, but what the jaqi considered an unnamed, fully malleable fetus. This fetus was the product of a conception that likely happened at a festival when the achachilas-a collectivity of earth spirits sometimes conflated in Arequipa today with an individual earth deity, the Pachamama - were paid through animal fat sacrifices and the celebratory spilling or urinating of corn beer into the earth. Achachilas reciprocated these communal sacrifices by providing the community with a fetus from their wet, dark inner world and would continue to reciprocate by providing fat to the fetus as it chose to follow the life-long path that leads to becoming jaqi. The basis of this cosmovision, part of which was likely widespread throughout the pre-Catholic Andes according to ancient ceramic depictions (Marín Benítez 2015), was that humans were not innately human. Rather, humans created themselves.

It is important to note, given the timeframe of the pre-Vatican II Catholic literature cited below, that this cosmology of human autocreation was much more at odds with Catholic cosmology in 1962 than it was in the 1990s when Canessa conducted his fieldwork among the jaqi of the Bolivian Andes. Mid-twentieth-century prevailing Catholic cosmology honored God alone as the creator of humanity. The eschatology of humanity involved merely returning to that state of original creation. Given the mismatch between the constructed humanity of some Andean Catholic communities and the God-given, essentialist humanity of the official Catholic church, it is no coincidence that one of the most successful theological integrations of these two poles occurred in Peru, one of the globe's most "Andean" and most Catholic nations. In 1973, Peruvian Dominican priest Gustavo Gutiérrez Merino gave a name to what, in my reading, is a melding of these two cosmologies: liberation theology. I have no evidence that he was actually thinking about Andean constructed personhood, but in A Theology of Liberation, Gutiérrez was thinking about the Bible, Karl Marx, and Paolo Freire when he boldly, and, as Pope John Paul II believed, blasphemously (Klaiber 1989) declared that "by working, transforming the world, breaking out of servitude, building a just society, and assuming its destiny in history, humankind forges itself" (Gutiérrez 1988, p. 90). Gutiérrez also based this theology on Gaudium Et Spes, a 1964 constitution resulting from Vatican II. Gutiérrez interpreted its brief mention of agrarian reform to mean that colonized land should be given back to humans (jaqi) who use earth-dependent cycles of reciprocity for the daily process of human forging, a process that does not end at death.

According to Canessa (2012), after death as an adult, a portion of the deceased jaqi would return to join the collective spirits of the inner world. Because that collectivity would then animate a new fetus, there was no sense of lineage from an individual ancestor, not even a parent. One was not jaqi because one was descended from jaqi and had essential jaqi characteristics, but because one lived as jaqi. Therefore, it was important to not become a $q^{\prime} a r a$, or a nonhuman, which is what jaqi considered Indigenous Bolivians (even their own children), mestizos, and white people who did not live in this cycle of reciprocity.

As if contending with these urban nonhumans were not enough, the jaqi also had to contend with the antihuman: the kharisiri. These are white specters thought to attack humans all over the Andes, suck the body fat constantly recycled between the upper world and the inner world, and sell it to capitalists to lubricate their machines. The 
kharisiri are from neither the inner nor the upper worlds and so cannot be reasoned with (Canessa 2012). This disastrous loss of the substance of personhood from a closed loop of reciprocity relates to the destruction of the entire Andean economy with the arrival of Spanish-style globalization and, if you will bear with me for a few more paragraphs, to the fear of destruction among contemporary carmenalteños regarding Mormon-style globalization.

Ancient Andean economies were based on the extreme ecological differences between slight variations in altitude characteristic of the Andes and the sharing of goods between these microclimates. This was a closed system because the sharing happened between those in the same allyu; colonists from the allyu were sent down the mountain to farm in each of the different climate zones. On a map, the territory of each allyu would look like a "vertical archipelago", and the rules of reciprocity stopped the accumulation of wealth on any single "island" (Murra 2002). Murra's (2002) description of the ancient Lupaqa kingdom near Puno and Lake Titicaca provides a poignant example of globalization's incompatibility with allyu economics. The new Spanish-appointed governor to the Lupaqa had an increasingly harder time getting the peasants to labor on their traditional allyu projects, including textile fabrication, because they were not seeing the reciprocity that was supposed to be inherent in the system. Like the kharisiri-syphoned body fat, the textiles were leaving the system while the governor accumulated an undue amount of personal wealth in return. He tried to make it seem like he was reinvesting this wealth back into the system by creating sumptuous Catholic churches that would feed the achachilas wheat hosts and wine (not cornbread and corn beer), but the people could see no ayni. As the fruit of their labor left their circle of relatedness, their collective personhood was in jeopardy.

After centuries, arequipeños with their own multivalent versions of constructed, substantialist personhood have found ways—such as liberation theology—to symbolically reabsorb these sumptuous Catholic churches into their cycles of reciprocity such that these edifices no longer count as antihuman accumulations of wealth. The relatively recent arrival of Mormon temples, on the other hand, are still far from adoption into arequipeño humanity.

\section{Vampires in Suits}

During my full year of ethnographic fieldwork in 2018, I officially joined a Mormon congregation in Arequipa. I was ostensibly in Arequipa to study transnational ties and migration between Peru and Utah, but I ended up following a bunch of other rabbit holes, one of which led to a mine shaft in nearby Toquepala, a mid-twentieth century company town connected to the same corporation that dug Utah's largest mining operation, which later became Kennecott Copper. The Utah connection meant that there were enough Anglo Mormon overseers in Toquepala in the 1950s for them to form their own congregation and to build Peru's first Mormon chapel, which, at almost nine thousand feet above sea level, was "the highest chapel of the Church in the world!" (Christensen 1995, p. 57). The piano from this English-speaking congregation, comprising as many as 40 Anglo Mormon families, eventually found its way to the skirts of the 19,000-foot-high volcano, Misti, and to the fingertips of one of the first arequipeñas to become Mormon, Leticia Lopez ${ }^{4}$. She has watched her church grow in Arequipa from 50 active members to 20,000, but she remains one of a handful who can play the piano. One evening, as I left her and her husband's large, middle-class home after one of our many interviews, she told me that I might be interested in talking to Hermana (Sister) Ordóñez, who was the Gospel Doctrine teacher of our congregation, Barrio Periféricos, ${ }^{5}$ and had been for over a decade. It was Hermana Ordóñez who bequeathed unto me the treasure trove of anti-Mormon literature that led to this and hopefully other articles. One of these articles will delve into the Mormoninfluenced beginnings of the US extractive industries in Peru that continue to sap Peru's

\footnotetext{
Pseudonym

5 Pseudonym.
} 
wealth, destroy Peru's environment, and line the pockets of Anglo Mormons to this day (Knowlton 2016). Though the present article is more spiritual in scope, it requires a mental image from the materiality of that future article: white Mormons detecting and extracting precious metals-golden plates as it were-from deep within the Peruvian earth, an earth, the Pachamama, that is still a revered goddess for many arequipeños regardless of their putative Catholicism. Arequipa's volcano, Misti (Figure 1), though also an apu (mountain god), is one of the Pachamama's many embodiments as well as the Catholic Virgin of Chapi's iconographic mirror image.

To various extents and valences, the economic and political ideal in many parts of the Andes has long been one of cyclical reciprocity with the Pachamama and the community. When wealth accumulates too much in the hands of a few members of that community, it is converted into food-and, most importantly, drink-and recycled back into the community and the earth through hugely expensive parties sponsored by those community members upon whom undue wealth has encrusted itself. Wealth must be liquified and returned to the cycle, ensuring its continuity. The greatest threat to this cycle is a leeching or crystallization of resources that clog the cycle or break away from it. In Andean mythology, this commonly happens in the form of caches of golden objects, such as golden bulls-not unlike the bull statues that uphold subterranean baptismal fonts inside Mormon temples-that lure travelers into deep caves from whence they never return (Arguedas 2012). The moral of most Andean fables that I have read is that wealth is not to be trusted. The arrival of the Catholics in 1532 did little to change this view, and Catholicism was eventually incorporated into the cycles of reciprocity that, at least symbolically, prevent wealth accumulation. The sponsoring of expensive Catholic patron saint festivals (Figure 2), baptisms, and quinceañeras is now part of the means through which many Catholics in the Andes cycle their life savings back into their communities just as their pre-Catholic ancestors did. Mormonism, along with other US-based Protestant religions, often causes arequipeño converts to see such expenditures as obscenely wasteful and antithetical to everything that they have been learning in their new, Salt Lake City-published Self-Reliance Initiative manuals. Their new religion motivates them to exit the cycle of reciprocity (Knowlton 1991), pack up their life savings, and climb aboard the unsustainable, upward trajectory of globalization, scarcity, and "eternal progress" (a Mormon theological concept) that often involves immigration to the US. Thus, to those non-Mormon carmenalteños influenced by substantialism and constructivism who value abundant, sustainable community, Mormonism is felt as a visceral threat to the ideal of cyclical reciprocity, which they already consider to be moribund in modern Arequipa.

For many non-Mormons in Arequipa, Mormonism represents a monstrous hoarding of resources akin to the great, white monster of the Andes, the kharisiri (Figure 3). For some of these arequipeños, gold is symbolic of solidified wealth. Like a blood clot, gold clogs the cycle. While gold is symbolic of that which wrecks the cycle, liquid body fat, which comes from digesting the food that the Pachamama provides, is symbolic of that which maintains and lubricates the cycle.

This is why the vampire of the Andes, the kharisiri, is so insidious. It does not take the time to solidify the substance of Andean personhood into the material form of money before it removes it from the cyclical system. Instead, it sucks that personhood, in the form of body fat, directly from its victims. As a recent Mormon convert from Puno, Peru, who knows a thing or two about the kharisiri from personal experience once told me,

you might be sitting on the bus next to a rich, white businessman in a suit and tie [not that dissimilar from an Anglo Mormon missionary] who is really the kharisiri in disguise. Without you noticing, as he sits next to you, he will stick you in the side with an extremely fine needle that you cannot feel, suck your body fat into a syringe, and sell your substance-rich in collagen and lipids-to cosmetic companies in the US.

Along with your body fat, the kharisiri extracts your personhood. If you cannot get to a skilled shaman in time, you will "dry up" and die within a matter of days. 


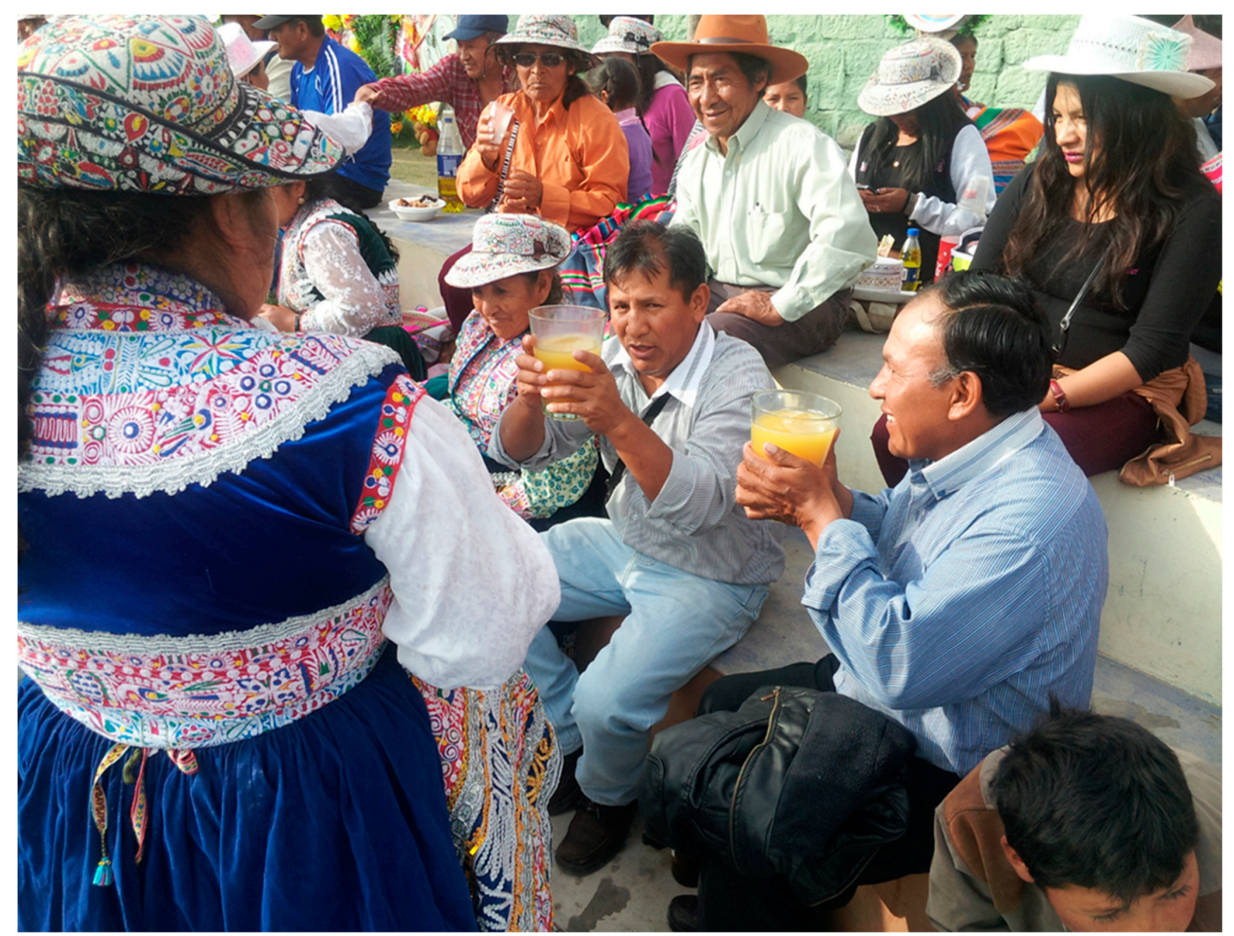

Figure 2. These migrants from the high-Andean town of Lari living in the mid-Andean city of Arequipa raise two communal glasses of homemade corn beer during Lari's Catholic patron saint festival after ch'allando (ceremonially spilling) some onto the ground for the Pachamama and before drinking and passing the glass to the next person waiting to dance. January 2018.

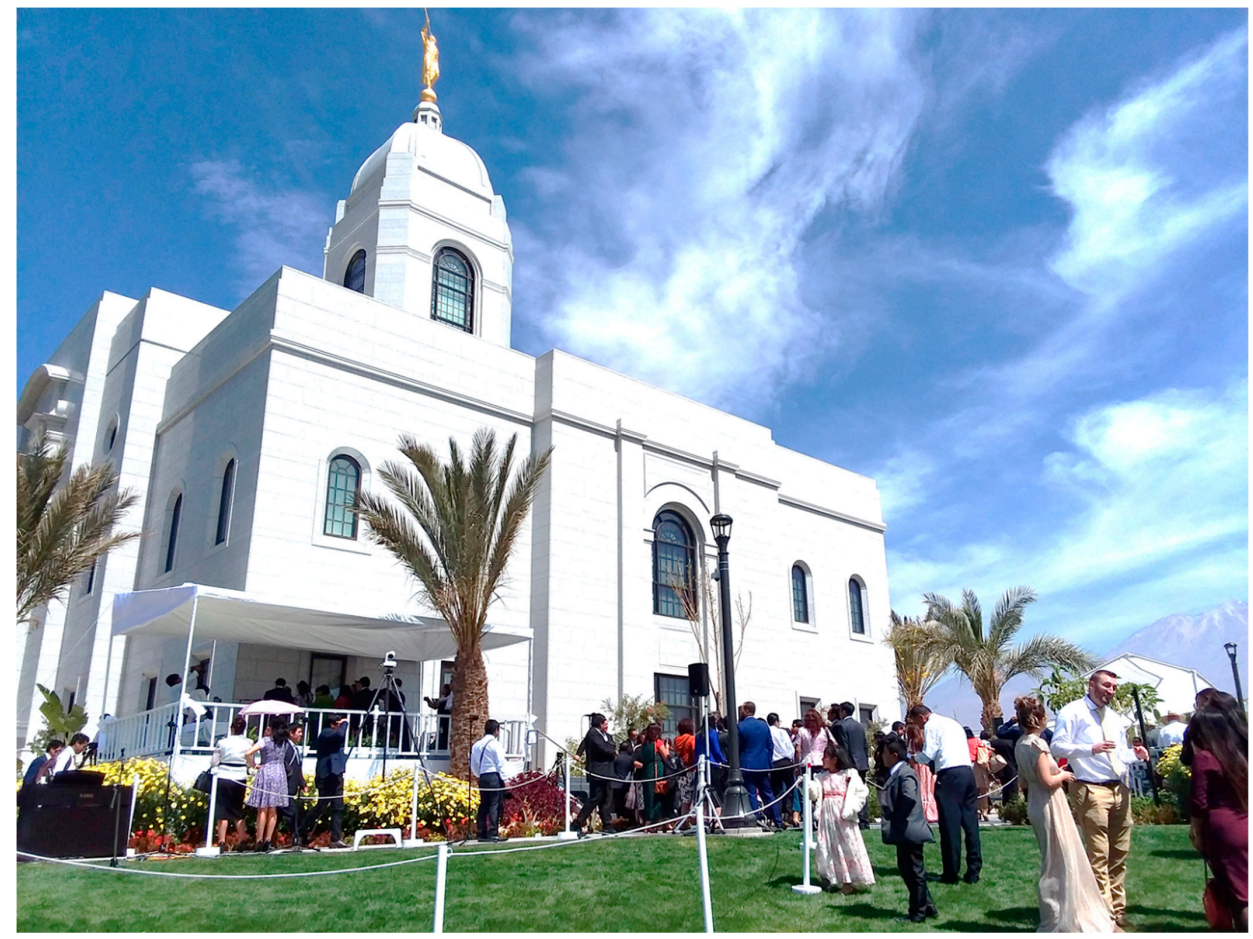

Figure 3. The Arequipa temple on the day of its dedication. Notice the golden statue. December 2019.

In one of the few anthropological studies on Mormonism in South America, Cesar Ceriani Ceriani Cernadas (2008) wrote of syncretic rumors in Argentina's Chaco designed by anti-Mormons to combine local toba fears with Mormon doctrine. As a result of the rumors, legend has it in the Chaco that Joseph Smith, the founder of Mormonism, was himself a vampire, syphoning the substance of toba cyclical connection and coagulating it 
into his coffers in Nauvoo, Illinois. In a less supernatural permutation of the legend, the people came to understand that Smith was a guerrilla fighter and that "the Mormons come to take away the blood of the girls and to kidnap the children" (p. 46). Either way, Anglo Mormon missionaries became semiotically solidified as globalizing agents who endanger toba lifeways. Many carmenalteños now see the new Mormon temple in their town through similar semiotics.

\section{Templar Stories}

Precisely because a place is densely knotted with significance, standing as an anchor point in some understanding of the world, new global flows and planetary stresses seem likely to send reverberations through the imaginations and stories by which it was set apart. (Jenkins 2020, p. 4)

During my fieldwork in Peru, I focused on the Mormon temple plot in Carmen Alto as a barometer of globalization in Arequipa because, as a place, it was densely knotted with significance even before an Anglo Mormon prophet set it apart as holy. This temple, completed and dedicated in December 2019, is now the ultimate solidification of visually striking wealth in a neighborhood that, of all the neighborhoods in Arequipa, is the most allergic to such a blatant display of hoarded money. The temple sits right on the edge of Carmen Alto, which, before the urban sprawl of Arequipa spread out to engulf it, was its own late colonial town complete with a town square and a Catholic church, destroyed in a 1960s earthquake (Figure 4). I spent many hours walking through its largely empty cobblestone streets trying to ascertain the general sentiment of the townsfolk toward the construction of this new node of globalization in their midst (Figure 5). Many are elderly semi-retired dairy farmers and fighting-bull breeders (Figure 6), proud of their rugged loncco identity and also proud of their staunch resistance to anything that might attack their traditional, fully arequipeño, Catholic way of life, a life for which, in their eyes, Carmen Alto is one of the last bastions. They are a dying breed, and many of them felt like their failure to ward off the Mormon temple was a nail in their coffin.

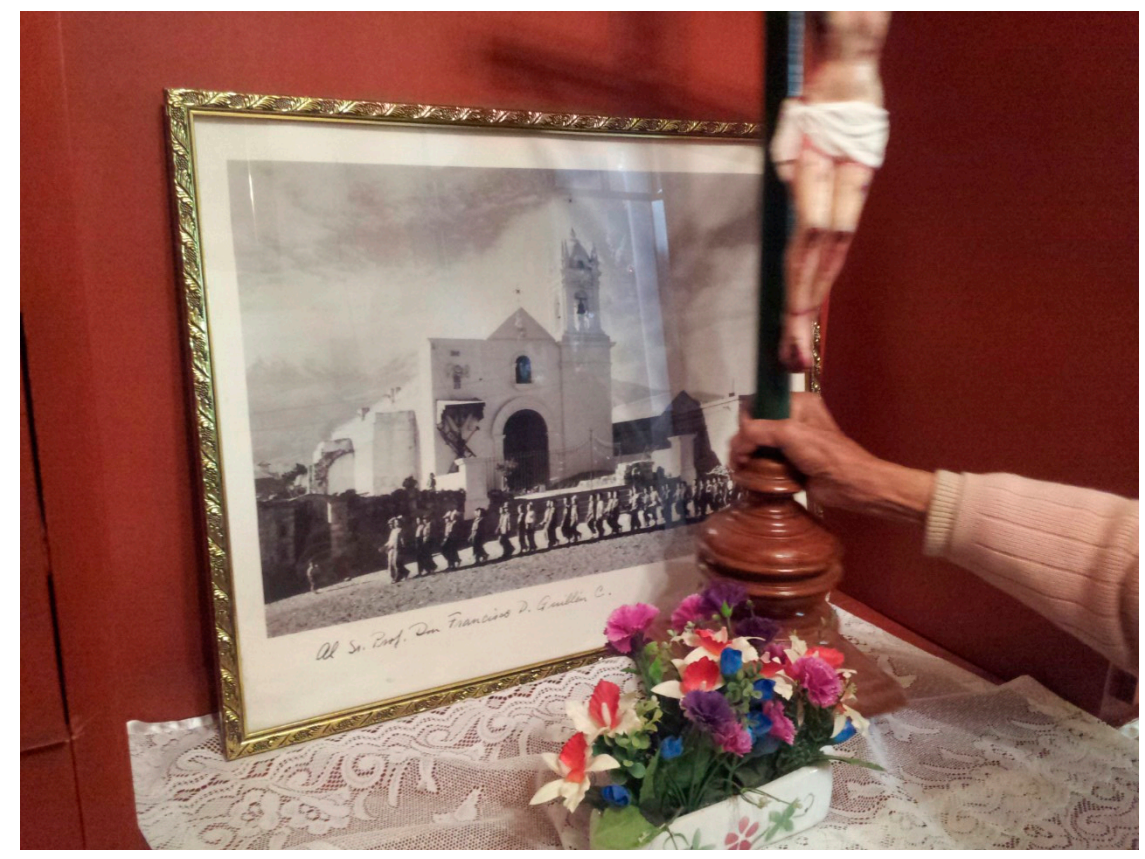

Figure 4. The caretaker of the Catholic church in Carmen Alto shows me a photograph of its original, late colonial church built in 1817. May 2018. 


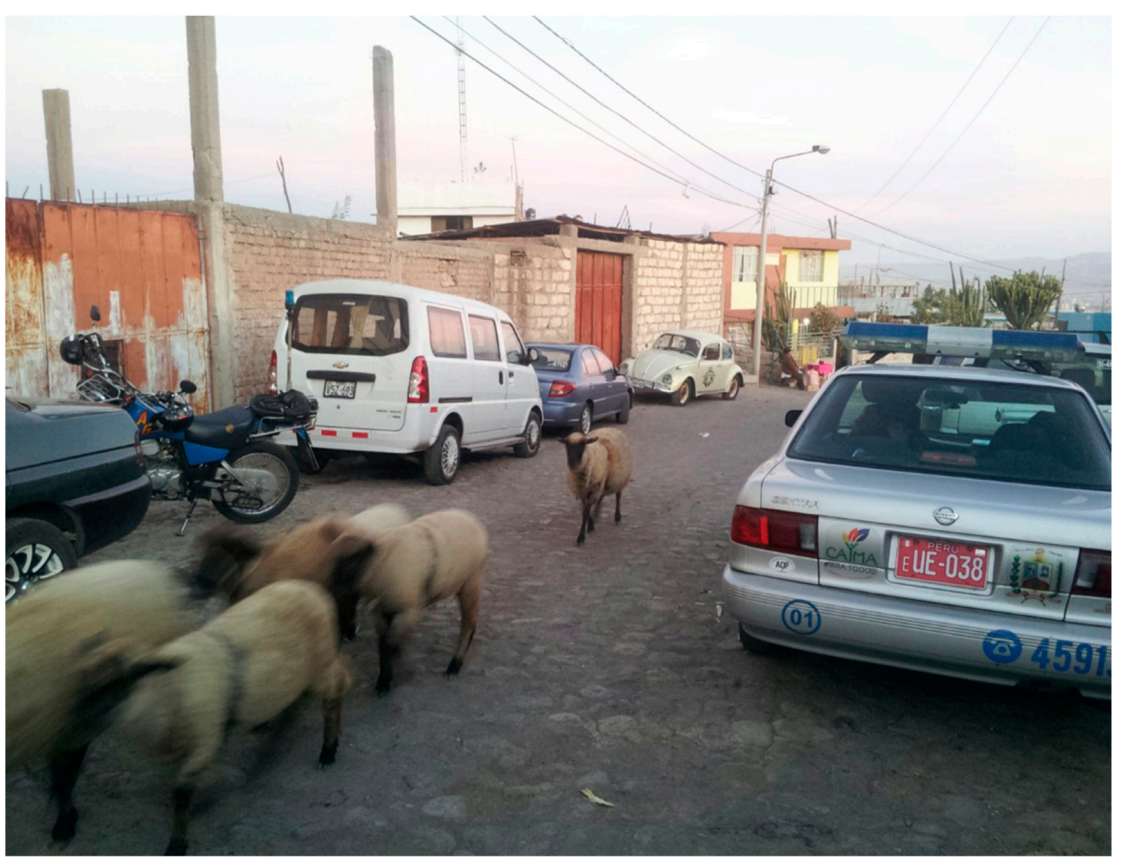

Figure 5. The street directly in front of the Mormon temple's construction entrance. May 2018.

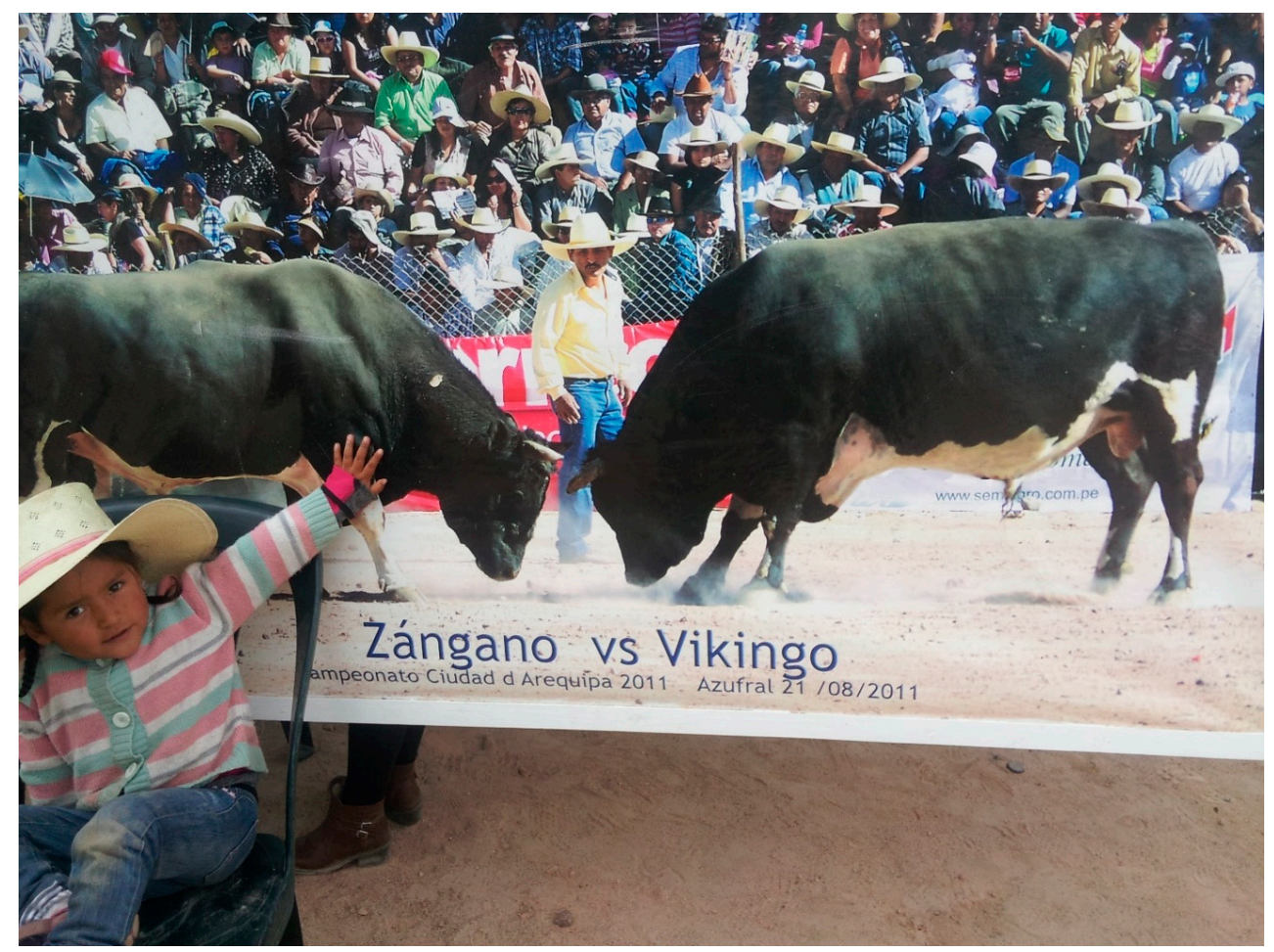

Figure 6. A young carmenalteña at Carmen Alto's annual Gran Feria Agroturística shows me which bull is her grandfather's. April 2018.

In my trips to Carmen Alto, I not only spoke to the townsfolk, but also to the Anglo Mormon orchestrators of the temple, the Peruvian construction workers, the Peruvian Ministry of Culture's archaeologists, the queso helado vendors, and any passersby who could give me an opinion on what was shaping up to be the most culturally inappropriate piece of architecture on the heretofore well-preserved arequipeño skyline. From the highly contradictory conversations and imaginings that resulted from my investigations, I was able to piece together a general story. 
Throughout the last half century, Anglo Mormon mission presidents in Peru have commented on a miraculous phenomenon: The Lord always opens doors for church property acquisition that were previously locked and barred. In 1960, one of these presidents wrote, "everywhere along the line, ways were opened up for us to get the exact property that we wished, at a very fair price" (Christensen 1995, pp. 74-75). Perhaps buoyed by this confidence that the Lord would provide, the church did something very uncharacteristic when it bought the land for the Arequipa temple: It bought the land without having permission to build on it. The land it bought was part of a designated green space within an archeologically protected area set aside by the National Ministry of Culture as an "intangible patrimony" because of its pre-Inca irrigation and agricultural terracing, which have been in continuous use for at least 3000 years and upon which the townsfolk of Carmen Alto still plant their corn and pasture their animals (Figure 7). The intangibility applied not to the stone terracing itself, but to the view that the terracing created, a view that continual farming enhanced but that large modern structures marred. Some neighbors of the temple had themselves previously bought the land upon which the temple now stands with the idea of forming a coop and building a high-rise apartment complex. They were not allowed to do so, however, because of the intangible patrimony restrictions. It was, therefore, common knowledge in the town that this space was undevelopable.

Yet, three years after the Mormons' billion-dollar corporation bought up the land in 2013, land upon which even it had no permission to build, Peru's National Ministry of Culture suddenly - and, perhaps, as the Anglo Mormon site manager of the temple told me, "miraculously" — changed the nationwide definition of "intangible patrimony" under law 28296 in the Mormon's favor (Figures 8 and 9). The change allowed Arequipa's mayor to pass his Metropolitan Development Master Plan, which lifted certain restrictions regarding the terracing. Suddenly, as long as they only built on thirty percent of the land and kept the rest "green", the Mormons could not only build, but build the tallest, most contextually mismatched edifice that Carmen Alto had ever seen (Figure 10). Considering the significance that the Book of Mormon assigns to the ancient inhabitants of the Americas, whom many Mormons believe were more authentically Christian than modern-day Catholics, it is easy to understand why the prophet and president of the church corporation would personally select this archaeologically rich plot of land for a temple. Of the first Mormon temple built in Peru-the Lima temple-a Church News correspondent wrote in 1986, "not since the Inca Empire was conquered four and a half centuries ago has a temple been erected in the northern regions of the Andes" (Hart 1986, p. 3). In their version of history, Mormons were not imposing Mormonism onto a pre-Christian site, they were restoring true Christianity to an ancient Mormon site.

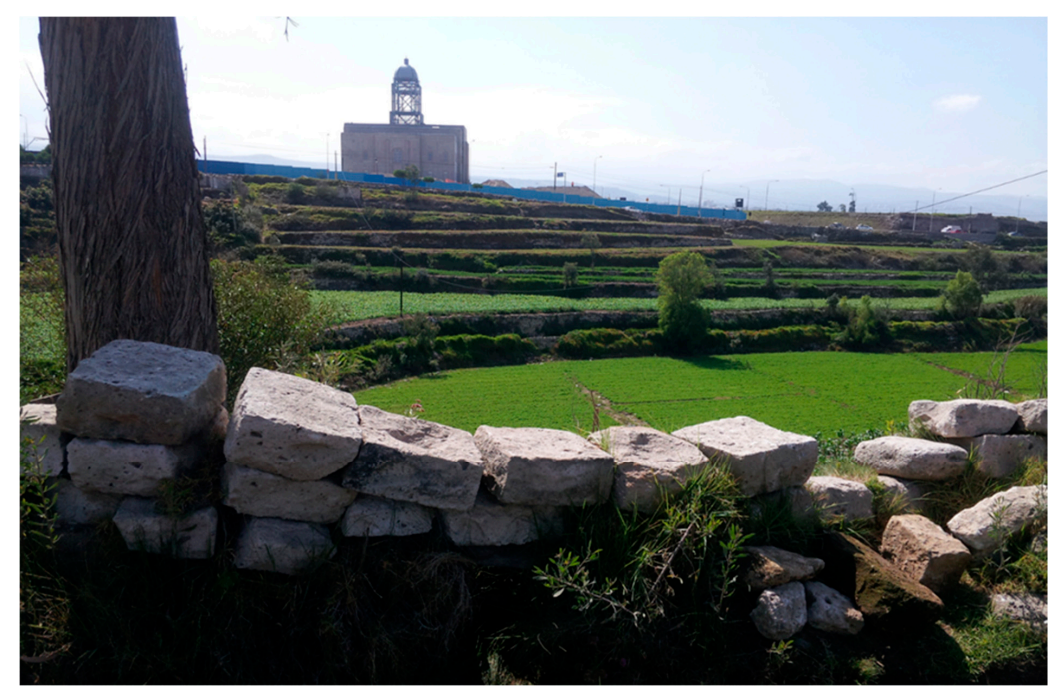

Figure 7. An unfinished Arequipa temple sits atop pre-Inca terracing that the Yarabaya people built over 3000 years ago. February 2018. 


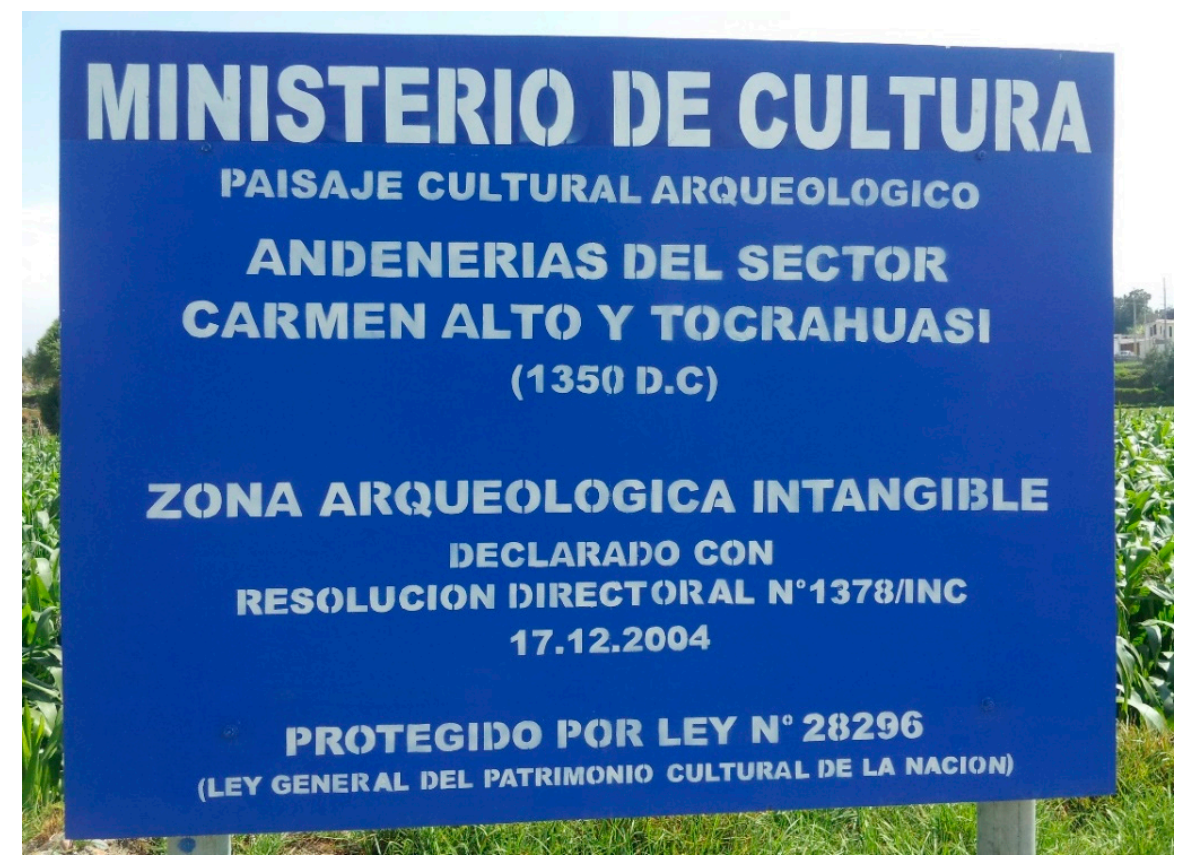

Figure 8. One of the many signs all over Carmen Alto legally protecting its bucolic view. February 2018.

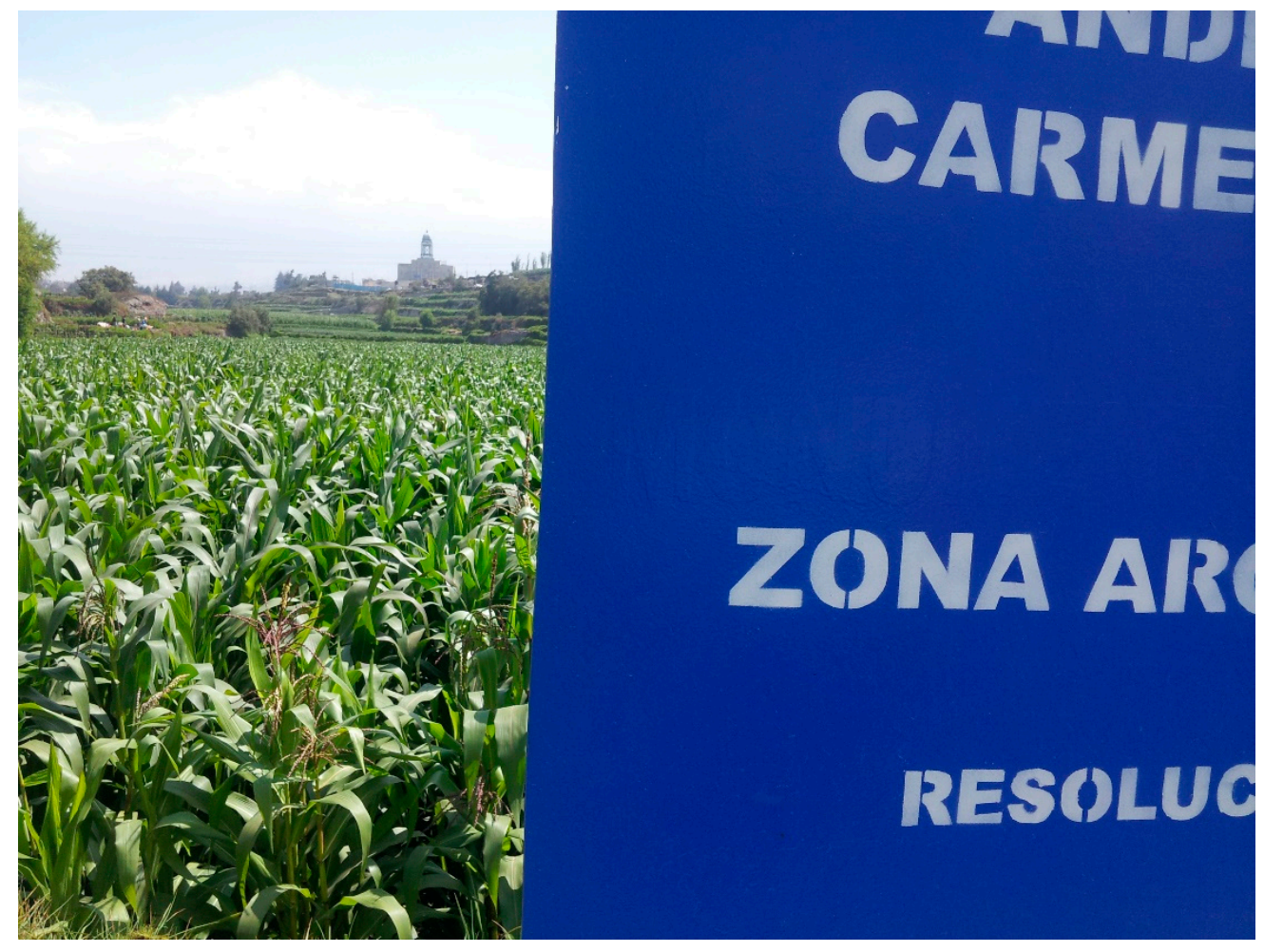

Figure 9. The Mormon temple emerges behind the very sign that once prohibited it. February 2018. 


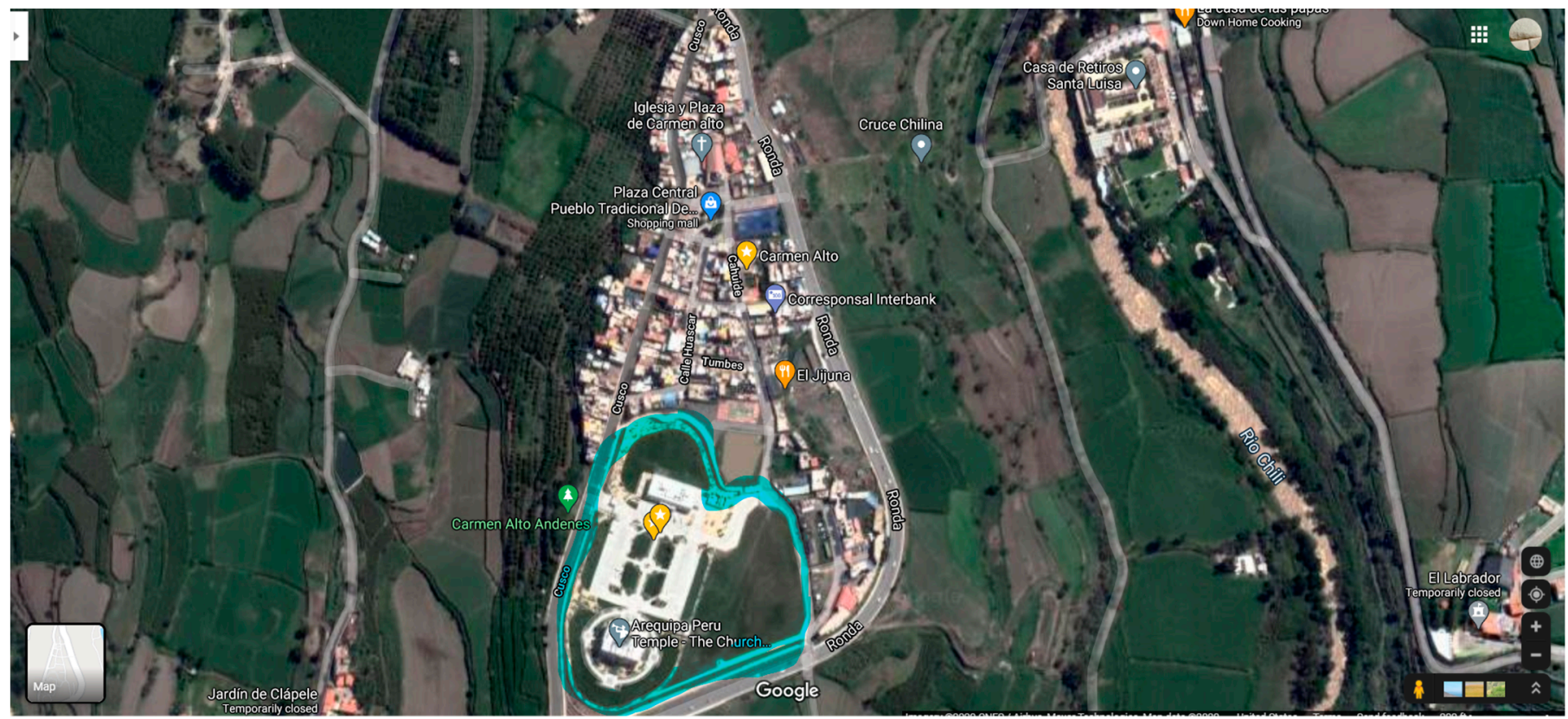

Figure 10. Though the Mormons only used thirty percent of their new property for the temple proper, the property itself, highlighted in blue in this Google Maps satellite image, occupies a whopping thirty-six percent of Carmen Alto, a town that previously had no Mormon presence whatsoever. Screenshot, August 2020.

Be that as it may, once the townspeople found out that their own federal governmentled by President Pedro Pablo Kuczynski, a former US citizen who made millions during his tenure at the World Bank and is currently under house arrest for corruption-had sold out their cultural patrimony to the Mormons, they took to the streets. The parish priest of Carmen Alto was able to obtain the signatures of almost every resident in Carmen Alto, and those of many former residents who still flock back to their hometown during its patron saint festivals, to submit a formal petition requesting that the Mormons not be allowed to build in his previously peaceful portion of arequipeño earth. The press took up this scandal (El Pueblo 2017), and with public opinion in their favor, the parishioners petition and other demonstrations seemed to be staving off the Mormon menace.

However, as the Anglo Mormon temple site manager gleefully told me, it just so happens that the archbishop of Arequipa, Javier Augusto del Río Alba, is a longtime co-presenter with none other than Mormon apostle Dallin Oaks at "religious freedom" and "gender ideology" conferences around the world, including Utah. Ideologically in bed with the Mormons, the archbishop commanded his subordinate, the parish priest of Carmen Alto, to stand down and rescind his petition.

On 23 March 2018, during one of my wanderings through Carmen Alto, I stopped and talked to an elderly woman who lived in a modest, brick home right in front of the main entrance of the recently commenced temple construction project. She was outside, harvesting spinach from her garden. Though she was extremely reticent, we had the following conversation:

JASON: What do you say about this temple that they've practically built in your front yard?

GARDENER: I say, if you have been baptized Catholic, how is it possible that you are going to become a Mormon? You can't. You would have to renounce, get rebaptized. How do they convince people to do it? A lot of people have told me that they buy converts off with free handouts. Me, why would I want to change religions? I am in the few remaining years before I go up to heaven.

As an ethnographer of Mormonism, I have become accustomed to interviewee tears. My interviewees cry regularly out of joy, sadness, or feelings of the Holy Ghost. However, 
I was not prepared for the type of crying that I was about to witness as our conversation continued. It is still gut wrenching when I listen to the audio recording. It is a cry of utterly impotent rage felt at the very core of personhood.

JASON: But what do you think about them putting this building right here? Some say that they are ruining the terracing, others say that it ruins the landscape, others say that it is beautiful-

GARDENER: - How can we resist it if they've bought it with their silver? The big and the powerful have accepted it. We are tiny compared to them with all their silver. They have money, they can do whatever they WANT! [crying].

JASON: Oh. [long silence]

GARDENER: With money they do EVERYTHING! And they might even be influencing the president as well [trying to recover from crying].

JASON: But if you were able to stop them, would you stop them?

GARDENER: Of course I would stop them if I could! But how can I stop them?

\section{Scrying Sonar}

As outsiders to all of the insider gaming and lobbying between leaders of countries and leaders of churches, the townsfolk of Carmen Alto came away with one lesson from the sudden fact of inaccessible Mormon opulence on their doorstep: Mormons have money, and apparently, money-a material object-trumps the will of a spiritual personage, God himself.

The townsfolk had been warned decades earlier about the metaphysical danger that the Mormons' conflation of spirit and matter would pose to their comparatively cyclical way of life. Anti-Mormon propaganda in Arequipa, though smattered with the classic critiques of polygamy almost as an afterthought, focused largely on what it portrayed as Mormonism's grotesque materialism. Most of the anti-Mormon pamphlets and newspaper articles circulating in Arequipa in the early 1960s were permutations of a decree that the excelentísimo and reverendísimo archbishop of Arequipa, Leonardo Rodriquez Ballón (1963), gave in the main Arequipa cathedral on 17 September 1962 in anticipation of the Vatican II proceedings that were to begin the following month. The decree was entitled, In Defense of the Faith, was exclusively about Mormons, and included an impressive works cited section including sociologist Thomas O'Dea's ethnographic account of a small Mormon town in Utah. The decree was published five months later in all of Arequipa's newspapers and, much like Mormonism's own encyclicals, was meant to be read from every local chapel in the city, including Carmen Alto. The archbishop's main point was that Mormonism was foolishly wasting its time trying to answer terrestrial questions that Catholicism had long rendered moot, such as, "who gave God the impulse of his existence and the motivation to be perfect? Where is God and what does he do all day"? (p. 2). In these inane questions, the archbishop argued, the Mormons were attributing to God insultingly quotidian material concerns.

In an arequipeño newspaper article that two North American Catholic officials wrote to lend weight to the Archbishop's decree, number two of the " 5 erroneous things that Mormons believe" was this: "THEY BELIVE THAT GOD HAS A BODY. This body is of the same race as humans. Joseph Smith said that 'The Father has a body of flesh and bone, tangible just like ours'" (Bowman and Chamberlain 1963, p. 7). Furthermore, in the eyes of these authors, as yet another example of how they "limit the power of the divine" (p. 7), Mormons said that God was not creative enough to find another way to start physical life on Earth or to physically have a son, and so He, like the most "repugnant" (Rodriquez Ballón 1963, p. 3) of the Greek gods, had to have sexual intercourse with both Eve and Mary. However, this was not the worst of Mormonism's materiality in the eyes of the Archbishop. Mormons claimed that God is limited by physical, human concerns, but then they had the gall to deny God even the creative human power that logically stems from those concerns. Citing Mormon scholar, James E. Talmage, the Archbishop wrote, 
"He is only given the power to organize the elements of the world, not to create them, for the simple reason that, according to Mormonism, such elements are eternal" (p. 1). Per the Archbishop, spiritual materialism led Mormons to claim that gold-as a mere element-was even more eternal than God. This made the Mormons' materially embodied god beholden to gold. The Mormon god, as a person of the same fallible race as humans, but somehow even less creative than humans, was a person who needed and accumulated gold. In the Andes, assuming my theorizing about substantialism and constructivism has any bearing on reality, such a declaration could only be interpreted one way: the Mormon god is antihuman.

The rest of the decree was full of terms laden with danger in the Andes because of the aforementioned mythology. The archbishop must have known the effect his phrasing would have on Andean Catholics as he related the stories of magic gold plates, Joseph Smith's property riddled with holes, slippery treasure, and the Abrahamic "catacombs of Egypt" (p. 2). The archbishop told of Joseph Smith's profession as a "zahori" or "water diviner, and not solely of aquatic currents, but also of precious metals. This induced him to believe in an influx of preternatural, occult powers in the environment that surrounds us" (p. 1). A few years later, rumors as to why Mormons were wanting to buy up property in "the environment that surrounds us" must have flown wildly in Arequipa, because one of its newspapers' 1964 headlines read, "Mormons Say: We Don't Want to Buy Your Catholic Temple" (Correo 1964, p. 2). The anonymous reporter was trying to get to the bottom of rumors that Mormons were going to buy a Catholic church. The article included an interview with one of the first arequipeño Mormons, Gomez de la Torre, who went on record as saying, "at no time have we ever been interested, nor will we ever be interested in buying a Catholic church since there are so many other lots we could acquire for the construction of our temples" (p. 2).

Today in Carmen Alto and throughout Arequipa, Mormons are known for doing exactly that: acquiring land. I went to one of Carmen Alto's patron saint festivals on 31 May 2018 and talked to three leathery loncco cattlemen (Figure 11). One of them had formulated his own theories, which he had pieced together from trusted sources, about the particular patterns of land acquisition that he had noticed among Mormons as he looked down from his high hilly fields upon the expanse of Arequipa below. Mormons did not just buy random plots of land for their 25 or so luxurious chapels, which now dot Arequipa (Figure 12). They did not place these chapels in relation to a preexisting concentration of arequipeño Mormons. It was the other way around. They picked each plot of land first and then converted enough people in the neighborhood around it to justify building a chapel on it, thus hiding the true value of the real estate. As the old man surmised, Mormons continue to buy these plots of land because they speculate, through a combination of Joseph Smith-style divination and modern sonar technology, that these are the very sites where meteorites penetrated the planet anciently, leaving huge lodes of diamonds embedded in the earth. Directly under each Mormon chapel in Arequipa-not to mention the holy temple itself-lays a diamond mine, which, at some future date, the Mormons will unearth. When that happens, as the old man assured me, "todos estamos jodidos" (we are all screwed). 


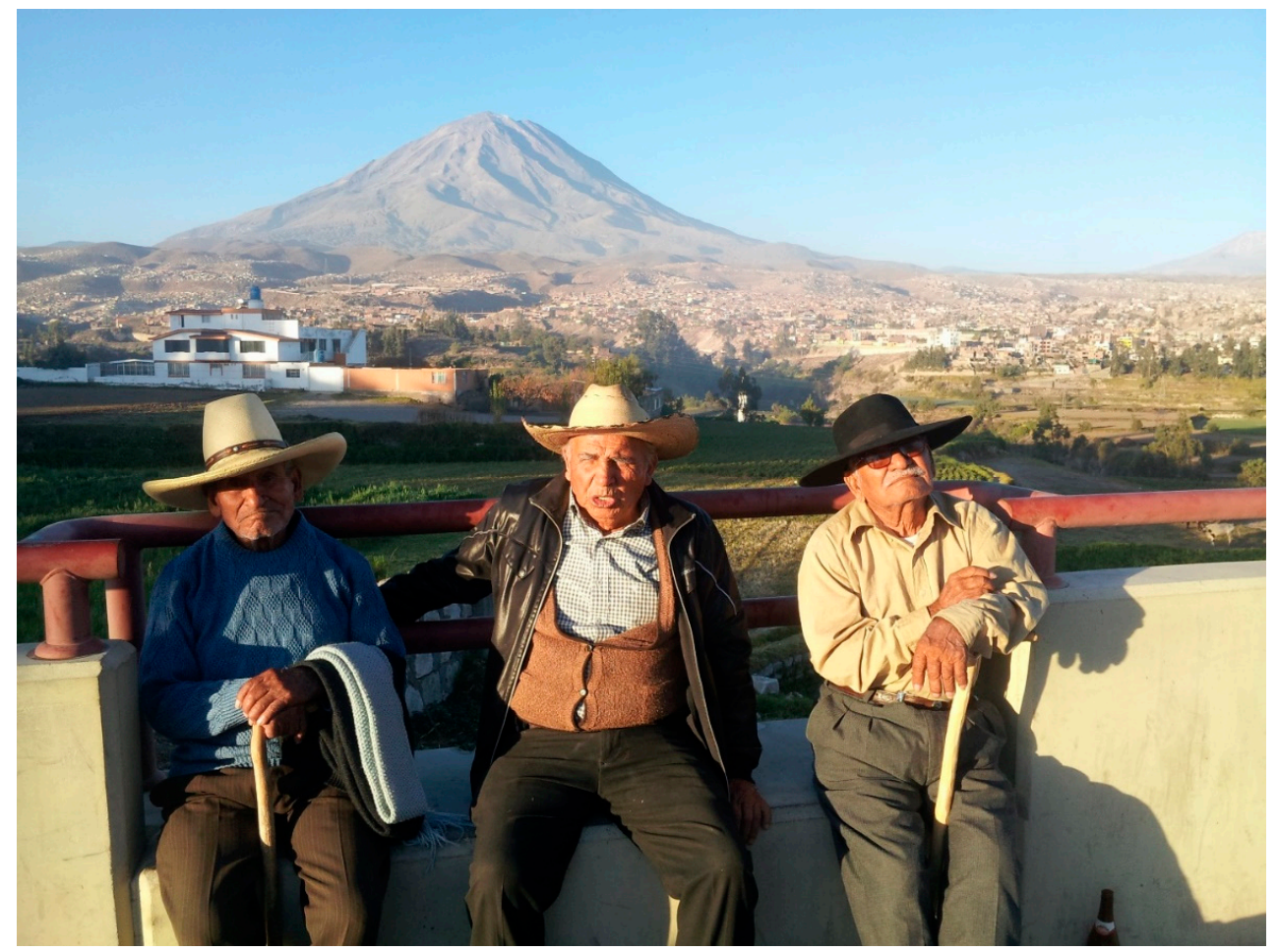

Figure 11. Loncco cattlemen in Carmen Alto pontificating on Mormon land speculation.

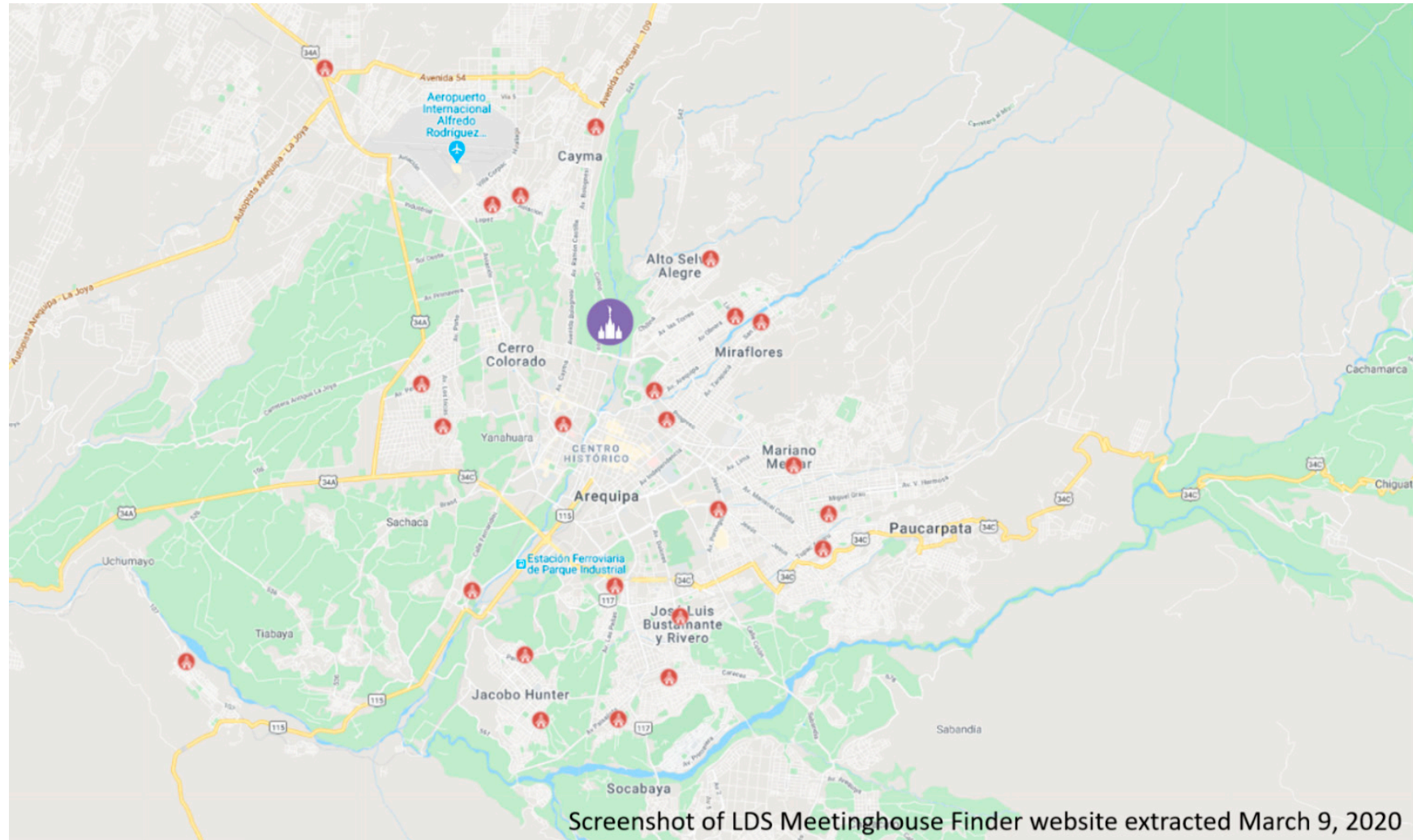

Figure 12. Per arequipeño lore, locations of subterranean mineral deposits in Arequipa align perfectly with the locations of Mormon chapels, marked in red. There may be something particularly valuable deep under the Mormon temple, marked in purple. 


\section{Substantial Shift}

For many carmenalteños and other Latin Americans, money means something different than it does to Anglo Mormons. When Anglo Mormons see money, many see prosperity, blessings, and holiness. After all, their most holy building is their most expensive building. When carmenalteños see money, many see trickery, danger, and evil. Their most sacred sites are priceless nonhuman people, often in the form of volcanoes, such as Misti, who play vital roles in keeping cycles of reciprocity lubricated and running. The apparent incommensurability of these two worlds, the Mormon and the arequipeño, gets reflected in the language that the Catholic church used to scare arequipeños away from Mormons. It also gets reflected in the resulting mythology of world-shifting—or world-screwing-buried treasure that continues to spring up around Mormon construction sites. Yet, somehow, some arequipeños become Mormons.

One point I am trying to make in exploring the implicit association of Mormons with lucre in Arequipa is that contrary to everyone's presuppositions-from my own academic mentors to the spinach gardener and from the first arequipeña Mormon pianist to the Anglo Mormon authors of the church's Self-Reliance Initiative manuals designed to dissuade members from asking for church handouts—arequipeños become Mormons despite money, not because of it. However, that is not the undergirding thrust of my argument. What I hope surfaces in the aftermath of my highly problematic pitting of carmenalteños against Anglos, Catholics against Mormons, cyclicity against upward mobility, fat against blood, God against gold, flowing against clotting, and globalization against indigeneity is a fundamental similarity between particular personhoods and universal humanity on this one globe that we all share.

The temple site at Carmen Alto is a microcosm of globalization's more unifying connotation. Sanctuary scientist Willis Jenkins (2020) wrote, "to experience a place as sacred is to participate, knowing or unknowingly, in a whole history of cultural tensions and conflicting claims, even ecological shifts in the terrain itself" (p. 4). Ajayu (dividual soul) is captured in the stone terracing in Carmen Alto's pre-Inca irrigation systems in much the same way carbon from the temple's construction backhoe's exhaust will be captured in stratospheric layers of ozone. Different substances are different things in different worlds, but those who gaze upon these words are all substantially connected on the same planet. The pre-Inca terracing of the Arequipa temple is sacred for both Mormons and Peruvians. After all, the governments of both Peru and the church set it apart as untouchable by all but a select few. The Mormons see it as the literal house of Heavenly Father. The Peruvians see it as the legacy of their forefathers. Thus, it is patrimony for both.

Yet, the Arequipa temple is also a microcosm of globalization's more disjunctive connotation. The Peruvian setting apart of the land is old whereas the Mormon church's setting apart is a new global flow akin to climate change. Religious change and climate change are both aspects of globalization common to the Anthropocene. John Doe burns carbon in New York, and people in the Maldives lose an island to rising sea levels. Joseph Smith sees a vision in New York, and people in Carmen Alto lose the view of their paradigmatic corn fields to a rising foreign structure capped with a dangerously golden statue. In these strange conflations of geographies and temporalities, globalization evokes not so much an unprecedented interconnectedness-we have always been part of the same greater ecology - as an unprecedented shift in the material and spiritual substances that make us human.

Funding: This research was partially funded by a Global Mormon Studies Research Grant at Claremont Graduate University.

Institutional Review Board Statement: The study was conducted according to the guidelines of the Declaration of Helsinki, and approved by the Institutional Review Board of the University of California, Irvine (HS\# 2015-2074. Approval Issued: 01/27/2017).

Informed Consent Statement: Informed consent was obtained from all subjects involved in the study. 
Data Availability Statement: Most data from this study are not available because of anonymity requirements. However, some anonymized data are available under the "Peruvian Mormonism" entry of the Database of Religious History at doi: 10.14288/1.0394981.

Conflicts of Interest: The author declares no conflict of interest.

\section{References}

Arguedas, José María. 2012. La Agonía de Rasu Niti. In Warma Kuyay y Otros Cuentos Peruanos. Lima: Impacto Cultural Editores S.A.C., pp. 31-42.

Bowman, Hieronimo, and Francisco Chamberlain. 1963. Análisis de La Doctrina Mormona. El Pueblo. February 12. Available online: https://drh-media-production.s3.amazonaws.com/attachments/entry/891/19630207\%20Bowman\%20and\%20 Chamberlain_1595871756_234cac.pdf (accessed on 30 March 2021).

Brooks, Joanna. 2018. Mormonism as Colonialism, Mormonism as Anti-Colonialism, Mormonism as Minor Transnationalism: Historical and Contemporary Perspectives. In Decolonizing Mormonism: Approaching a Postcolonial Zion. Edited by Gina Colvin and Joanna Brooks. Salt Lake City: University of Utah Press, pp. 163-85.

Busby, Cecilia. 2006. Renewable Icons: Concepts of Religious Power in a Fishing Village in South India. In The Anthropology of Christianity. Edited by Fenella Cannell. Durham: Duke University Press Books, pp. 77-98.

Canessa, Andrew. 2012. Intimate Indigeneities: Race, Sex, and History in the Small Spaces of Andean Life. Durham: Duke University Press.

Ceriani Cernadas, Cesar. 2008. Vampiros En El Chaco. Rumor, Mito y Drama Entre Los Toba Orientales. Indiana 25: 27-49.

Christensen, Dale. 1995. History of the Church in Peru. Scotts Valley: CreateSpace Independent Publishing Platform.

Correo. 1964. Mormones: No Queremos Comprar Templo Católico. Correo. March 9. Available online: https://drh-media-production. s3.amazonaws.com/attachments/entry /891/19640509\%20Correo\%20no\%20templo_1595871756_debc06.pdf (accessed on 30 March 2021).

De La Cadena, Marisol. 2000. Indigenous Mestizos: The Politics of Race and Culture in Cuzco, Peru, 1919-1991. Durham: Duke University Press.

El Pueblo. 2017. Mormones Continúan Con La Construcción de Templo En Cayma. Diario El Pueblo. August 11. Available online: https:/ / diarioep.pe/mormones-continuan-con-la-construccion-de-templo-en-cayma/ (accessed on 30 March 2021).

Escuela Tipográfica Salesiana. 1964. Alerta Con Los Mormones. Arequipa: Escuela Tipográfica Salesiana. Available online: https:/ /drhmedia-production.s3.amazonaws.com/attachments/entry/891/19630000\%20Escuela\%20Salesiana_1595871756_81e26d.pdf (accessed on 30 March 2021).

Franklin, Sarah. 2002. Biologization Revisited: Kinship Theory in the Context of the New Biologies. In Relative Values: Reconfiguring Kinship Studies. Edited by Sarah Franklin and Susan McKinnon. Durham: Duke University Press, pp. 302-25.

Gandolfo, Daniella. 2009. The City at Its Limits: Taboo, Transgression, and Urban Renewal in Lima. Chicago: University of Chicago Press.

Gutiérrez, Gustavo. 1988. A Theology of Liberation: History, Politics, and Salvation, 15th Anniversary ed. Maryknoll: Orbis Books.

Harrison, Regina. 2015. Sin and Confession in Colonial Peru: Spanish-Quechua Penitential Texts, 1560-1650, Reprint ed. Austin: University of Texas Press.

Hart, John L. 1986. Temples Received with Thanks. Prophecy Fulfilled for Peru Members. Church News, January 26.

Jenkins, Willis. 2020. Sacred Places and Planetary Stresses: Sanctuaries as Laboratories of Religious and Ecological Change. Religions 11: 215. [CrossRef]

Klaiber, Jeffrey L. 1989. Prophets and Populists: Liberation Theology, 1968-1988. The Americas 46: 1-15. [CrossRef]

Knowlton, David. 1991. Social and Political Issues of Protestantism in Bolivia. Paper presented at the 90th American Anthropological Association Annual Meeting, Chicago, IL, USA, November 20-24.

Knowlton, David. 2016. What Happened When Mormons Came to Mine and Build Peru? Clouds, Storms, and Power. (blog). Available online: http:/ / stormsandpower.blogspot.com/2016/04/what-happened-when-mormons-came-to-mine.html (accessed on 30 March 2021).

Marín Benítez, Ciro. 2015. Filosofía Tawantinsuyana: Una Perspectiva Epistémica. Lima: Juan Gutemberg Editores Impresores.

Martínez, María Elena. 2011. Genealogical Fictions: Limpieza de Sangre, Religion, and Gender in Colonial Mexico. Stanford: Stanford University Press.

Murra, John V. 2002. El Mundo Andino: Población, Medio Ambiente, y Economía. Lima: Pontificia Universidad Católica del Perú.

Nash, June. 1993. We Eat the Mines and the Mines Eat Us: Dependency and Exploitation in Bolivian Tin Mines, rev. ed. New York: Columbia University Press.

O'Brien, Thomas. 1999. The Century of U.S. Capitalism in Latin America. Albuquerque: University of New Mexico Press.

Palmer, Jason, and David Knowlton. 2020. Mormons in Peru: Building Temples with Sacred Cornerstones and Holy Drywall. In The Palgrave Handbook of Global Mormonism. Edited by Shepherd R. Gordon, A. Gary Shepherd and Ryan T. Cragun. New York: Palgrave Macmillan, pp. 397-419.

Rodriquez Ballón, Leonardo. 1963. En Defensa de La Fe. El Pueblo. February 7-10. Available online: https:/ /drh-media-production.s3 .amazonaws.com/attachments/entry/891/19630207\%20Rodriguez\%20Ballon_1595871756_6474b8.pdf (accessed on 30 March 2021). 
Rumble, Leslie. 1974. [1959] The Mormons. London: The Incorporated Catholic Truth Society. Available online: https: / / drh-media-production.s3.amazonaws.com/attachments/entry/891/19590000\%20The\%20Mormons\%20\%281974\%20 ed\%29\%2C\%20Rumble_1595871756_fcbf32.pdf (accessed on 30 March 2021).

Tuck, Eve, and K. Wayne Yang. 2012. Decolonization Is Not a Metaphor. Decolonization: Indigeneity, Education E Society 1: 1-40.

Vega, Alejandra. 2008. La pérdida del alma y la etiología de un taxón tradicional: el Susto entre los migrantes Aymara de Buenos Aires. V Jornadas de Sociología de la Universidad Nacional de La Plata 28: 1-10.

Viveiros De Castro, E. 1998. Cosmological Deixis and Amerindian Perspectivism. Journal of the Royal Anthropological Institute 4: 469-88. [CrossRef]

Wallerstein, Immanuel. 2004. World-Systems Analysis: An Introduction. Durham: Duke University Press.

Zimmermann, Warren. 1998. Jingoes, Goo-Goos, and the Rise of America's Empire. Wilson Quarterly 22: 42. 